\title{
1 Biochar physico-chemical properties as affected by environmental \\ 2 exposure
}

3

$4 \quad$ Research article

5 Authors:

6 Giovambattista Sorrenti $^{\mathrm{a}^{*}}$, Caroline A. Masiello $^{\mathrm{b}}$, Brandon Dugan $^{\mathrm{c}}$, Moreno Toselli $^{\mathrm{a}}$

7

8 Author's affiliation and address:

$9 \quad{ }^{\mathrm{a} D e p a r t m e n t}$ of Agricultural Sciences, University of Bologna, viale G. Fanin 44, 40127

10 Bologna, Italy, g.sorrenti@unibo.it, moreno.toselli@unibo.it

$11{ }^{\mathrm{b}}$ Departments of Earth Science, BioSciences, and Chemistry, Rice University, Houston,

12 Texas 77005, USA, masiello@rice.edu

$13{ }^{\mathrm{c}}$ Department of Earth Science, Rice University, Houston, Texas 77005, USA,

14 dugan@rice.edu

15

$16 *$ Corresponding author:

17 Giovambattista Sorrenti

18 Department of Agricultural Sciences, University of Bologna, viale G. Fanin 44, 40127

19 Bologna, Italy

20 e-mail: g.sorrenti@unibo.it

21 Telephone number: +390512096426

22 Fax number: +390512096401 


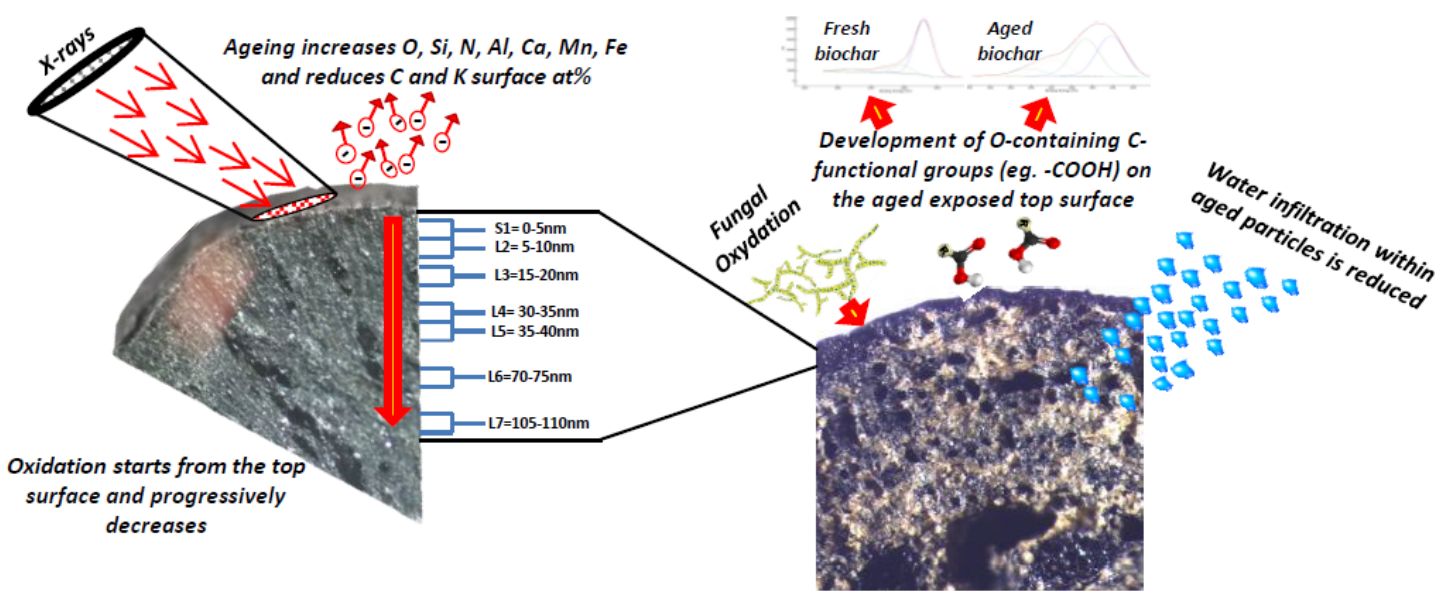

\section{Abstract}

To best use biochar as a sustainable soil management and carbon (C) sequestration technique, we must understand the effect of environmental exposure on its physical and chemical properties because they likely vary with time. These properties play an important role in biochar's environmental behavior and delivery of ecosystem services. We measured biochar before amendment and four years after amendment to a commercial nectarine orchard at rates of 5, 15 and $30 \mathrm{tha}^{-1}$. We combined two pycnometry techniques to measure skeletal $\left(\rho_{\mathrm{s}}\right)$ and envelope $\left(\rho_{\mathrm{e}}\right)$ density and to estimate the total pore volume of biochar particles. We also examined imbibition, which can provide information about soil hydraulic conductivity. Finally, we investigated the chemical properties, surface, inner layers atomic composition and $\mathrm{C} 1 \mathrm{~s}$ bonding state of biochar fragments through X-ray photoelectron spectroscopy (XPS). Ageing increased biochar skeletal density and reduced the water imbibition rate within fragments as a consequence of partial pore clogging. However, porosity and the volume of water stored in particles remained unchanged. Exposure reduced biochar $\mathrm{pH}, \mathrm{EC}$, and total $\mathrm{C}$, but enhanced total $\mathrm{N}$, nitrate- $\mathrm{N}$, and ammonium-N. X-ray photoelectron spectroscopy analyses showed an increase of $\mathrm{O}, \mathrm{Si}, \mathrm{N}, \mathrm{Na}, \mathrm{Al}, \mathrm{Ca}, \mathrm{Mn}$, and Fe surface $(0-5 \mathrm{~nm})$ atomic composition $($ at $\%)$ and a reduction of $\mathrm{C}$ and $\mathrm{K}$ in aged particles, confirming the interactions of biochar with soil inorganic and organic phases. Oxidation of aged biochar fragments occurred mainly in the particle surface, and progressively decreased down to $75 \mathrm{~nm}$. 
Biochar surface chemistry changes included the development of carbonyl and carboxylate functional groups, again mainly on the particle surface. However, changes were noticeable down to $75 \mathrm{~nm}$, while no significant changes were measured in the deepest layer, up to $110 \mathrm{~nm}$. Results show unequivocal shifts in biochar physical and chemical properties/characteristics over short ( $\sim$ years) timescales.

Keywords: Charcoal, Density, Porosity, Imbibition, XPS, Ageing

\section{Introduction}

Biochar is the solid residue of biomass pyrolysis intentionally added to soil to sequester carbon (C) (Woolf et al., 2010), to ameliorate soil properties (Spokas et al., 2012) and to improve crop performance (Verheijen et al., 2010). Many biochar-induced ecosystem services, including improving soil water properties and ions retention, are due to its high $(\sim 75 \%)$ porosity which indicates the fraction of the total fragment volume not filled by solid (Brewer et al., 2014). Interconnected biochar pores are arranged in complex structures (Nguyen et al., 2010) and range from less than $1 \mathrm{~nm}$ (Sun et al., 2012; Keiluweit et al., 2010;) to pores on the order of $0.01 \mathrm{~mm}$ in size, reflecting the cellular arrangement of the pyrolyzed feedstocks (Bird et al., 2008; Wildman et al., 1991) Pore surface area and reactivity control biochar sorptive capacities and modulate its interactions with minerals, water, microbes, fungal hyphae and plant roots (Downie et al., 2009; Thies and Rilling, 2009; Chen et al., 2008; Warnock et al., 2007; Hockaday et al., 2006; Pietikäinen et al., 2000). Recent findings suggest that pores $>50$ nanometers ( $\mathrm{nm}$ ) are responsible for most of the biochar porosity (Brewer et al., 2014),. This result has been validated using mercury porosimetry by Baltrenas et al. (2015) who estimated that up to $90 \%$ of either birch or pine-derived biochar pore volume consisted of pores larger than $500 \mathrm{~nm}$ in diameter while pores less than 500 $\mathrm{nm}$ took less than $1.5 \%$ of the total pore volume. Similarly, Laine et al. (1992) report than activated 
charcoal micropore surface area is larger than macropore surface area, but macropore volumes can be more than double than micropore volume. Macropores affect hydraulic conductivity (Masiello et al., 2015; Barnes et al., 2014; Brockhoff et al., 2010; Oguntunde et al., 2008) and other hydrologic processes (e.g. infiltration, erosiveness, wettability, water retention, nutrient leaching) (Baronti et al., 2014; Bruun et al., 2014; Novak et al., 2012; Major et al., 2009). These properties impact microbial habitats (Lehmann et al., 2011), offering shelters for mycorrhizal fungi (Warnock et al., 2007).

Biochar physico-chemical properties may change after environmental exposure, challenging our ability to predict its long-term ecosystem services. Changes result from shifts in temperature, water content, tillage, fertilization and interactions with the soil matrix (Joseph et al., 2010). Density and porosity of biochar can be altered through the trapping of minerals, roots, OM or microbes, (Jaafar et al., 2014; Warnock et al., 2007) shifting biochar sorption capacity, soil hydraulic conductivity and water retention.(Masiello et al., 2015; Baronti et al., 2014).

Several studies report changes of biochar properties as a consequence of ageing (LeCroy et al., 2013; Lin et al., 2012; Jones et al., 2012; Joseph et al., 2010; Zimmerman, 2010; Cheng et al., 2008) However, most of these findings come from environmental exposures $<6$ months or weathering induced through chemical and/or physical treatments (Yao et al., 2010).

Similarly, some studies suggest that oxidation is a surface process; others report oxidation throughout particles (Cheng et al., 2006). It seems reasonable to assume that chemical changes start at the surface, but no information exists about the progression of the oxidation front.

We evaluated porosity shifts induced by 4 years of environmental exposure by comparing fresh (never applied to the field) and field-applied biochar from the same biochar batch. We combined two pycnometry techniques to determine skeletal $\left(\rho_{\mathrm{s}}\right)$ and envelope $\left(\rho_{\mathrm{e}}\right)$ densities which allow estimation of porosity of biochar particles (Brewer et al., 2014). We also evaluated hydrologic implications of biochar ageing by an imbibition assay. Finally, we measured chemical properties, surface, inner layers elemental composition and $\mathrm{C} 1 \mathrm{~s}$ bonding state of biochar through X-ray 
photoelectron spectroscopy (XPS). We hypothesized that i) environmental exposure generates physical-chemical changes of biochar fragments, ii) chemical changes are not limited to the top exposed surface iii) the extent of the changes may be rate-dependent and iv) ageing alter biocharwater interactions.

\section{Materials and Methods}

\subsection{Experimental site and biochar characteristics}

A four-year experiment was carried out using a commercial nectarine (Prunus persica L., Batsch) orchard (Big Top/GF677) planted in 1997 with a density of 519 trees ha $^{-1}$ (3.5 x $5.5 \mathrm{~m}$ ) located in the southeastern Italian Po Valley (Tebano, Ravenna, 44 $29^{\prime}$ N, $11^{\circ} 78^{\prime} \mathrm{E}, 58 \mathrm{~m}$ a.s.1.) on a sandyloam Inceptisol soil with $\mathrm{pH}=8.08$, organic matter $(\mathrm{OM})=10.6 \mathrm{~g} \mathrm{~kg}^{-1}$, cation exchange capacity $(\mathrm{CEC})=13.0 \mathrm{meq} 100 \mathrm{~g}^{-1}$, and total $\mathrm{N}$, available $\mathrm{P}$, exchangeable $\mathrm{K}, \mathrm{Na}, \mathrm{Ca}$, and $\mathrm{Mg}$ of $800,8,97$, 37,2347 , and $109 \mathrm{mg} \mathrm{kg}^{-1}$.

The area has a temperate sub-continental climate with cold winters and warm, humid summers $\left(\mathrm{T}_{\text {average }}=13.6^{\circ} \mathrm{C} ; \mathrm{T}_{\text {highest }}=40.5^{\circ} \mathrm{C}, \mathrm{T}_{\text {lowest }}=-4.1^{\circ} \mathrm{C}\right)$. Annual precipitation ranged between 650 and $910 \mathrm{~mm}$. Alleys were maintained with native grass species while tree rows were herbicided with glufosinate ammonium (DL-phosphinothricin). Trees were managed by pruning, thinning, fertilization, irrigation, and control of pest and disease according to regional guidelines (ICM, 2009). From May to August trees were drip-irrigated and yearly fertilized with $0.25 \mathrm{~kg} \mathrm{~N}$ tree ${ }^{-1}$ (130 $\mathrm{kg} \mathrm{N} \mathrm{ha}^{-1}$ ) as urea at petal fall.

The biochar we used was produced in a commercial slow-pyrolysis unit (Romagna Carbone snc, Bagnacavallo (RA), Italy) using cylindrical, vertical charcoal kiln of $8.14 \mathrm{~m}^{3}$ (2.40 m diameter and $1.80 \mathrm{~m}$ height). We used non-contaminated chipped hardwood (peach and grapevine at the same rate $\left(\mathrm{v} \mathrm{v}^{-1}\right)$ pruning wood) slowly pyrolyzed with continuous (150 min) heating from ambient temperature (heating rate of $10-15^{\circ} \mathrm{C} \mathrm{min}^{-1}$ ), reaching the highest $\mathrm{T}$ of $\sim 550^{\circ} \mathrm{C}$ with a 30 min peak 
temperature hold time (Tab. S1). Charred fragments were allowed to cool to ambient conditions in the absence of $\mathrm{O}_{2}$.

\subsubsection{Experimental design}

In November 2009 we distributed biochar at the rates of 5, 15, and $30 \mathrm{t}$ fresh weight (fw) ha ${ }^{-1}$ according to a randomized experimental block design, with 5 replicates of 5 trees each, arranged in 4 consecutive tree rows, leaving 10 unamended meters between consecutive plots. Treatments were randomly distributed in each row with at least one replicate per biochar rate in each row. Biochar was distributed on a $35 \mathrm{~m}^{2}$ area per experimental plot ( $2 \mathrm{~m}$ wide along the herbicided strip) and mixed into the first 20-cm soil depth (A horizon) by a disc harrow. Control samples of biochar (never field-applied, termed here "fresh") were hermetically stored in plastic bags four years.

\subsubsection{Biochar recovery}

We randomly recovered (Nov-13) 50 biochar fragments of different sizes from each replicate. To accomplish this we removed the first 3-5 cm depth of the soil layer and carefully collected fragments from the soil by forceps, avoiding manual contact or any physical damage to the particles. We sealed the particles in polyethylene bags and transported them to the laboratory in a portable refrigerator. A composed biochar sample of $\sim 2.5 \mathrm{~kg}$ (never field-applied, termed here "fresh") from the same biochar batch (from a unique and homogenized heap of $\sim 2 t$ ) was stored in hermetically closed plastic bags of $\sim 250 \mathrm{~g}$ ea. and maintained four years at room temperature, in a dry and dark place. After four years, a random subset of these stored fresh biochar fragments $(\sim 100$ pieces) were isolated by forceps, transferred in several test tubes, then analyzed as the soilrecovered biochar fragments.

Particles were dried at $50{ }^{\circ} \mathrm{C}$ for $72 \mathrm{~h}$, sieved to $1 \mathrm{~mm}$ and the surface of individual fragments (keeping each piece by forceps under a magnifying lens) was cleaned with a soft brush and rinsed 
twice with deionized water $\left(\mathrm{DI}-\mathrm{H}_{2} \mathrm{O}\right)$ to remove adhering soil. Fragments were not physically damaged during handling and drying.

\subsection{Biochar physical changes as affected by the environmental exposure}

\subsubsection{Skeletal density $\left(\rho_{s}\right)$}

Skeletal density $\left(\rho_{\mathrm{s}}\right)$ is the mass of a particle divided by its volume and was determined by helium

(He) pycnomentry. We measured the $\rho_{\mathrm{s}}$ of $\sim 0.1 \mathrm{~g}$ dry biochar mass per replicate (samples composed of about 5-6 fragments, with each piece smaller than $1 \mathrm{~cm}^{3}$ ) using an AccuPyc 1340 (Micromeritics, Norcross, GA) fitted with a $1 \mathrm{~cm}^{3}$ chamber (Brewer et al., 2014).

\subsubsection{Envelope density $\left(\rho_{e}\right)$}

Envelope density $\left(\rho_{\mathrm{e}}\right)$ is the mass of a dry biochar sample divided by the volume of its non-wetting exterior measured if an "envelope" were placed around each individual particle (Brewer et al., 2014). We measured $\rho_{\mathrm{e}}$ of biochar samples that were $\sim 0.215 \mathrm{~g}$ (dry mass) per replicate (samples composed of about 8-9 fragments, with each piece smaller than $1 \mathrm{~cm}^{3}$ ) using a Geopyc 1360 Envelope Density Analyzer (Micromeritics, Norcross, GA). Fragments were placed in a bed of DryFlo $^{\circledR}$ granular medium (density of $\sim 0.4 \mathrm{~g} \mathrm{~cm}^{-3}$ ). Consolidation was achieved by continuous rotation and vibration of the cylindrical chamber as the piston was gradually pushed into the chamber until the stated $22 \mathrm{~N}$ force was reached (Brewer et al., 2014).

\subsubsection{Porosity}

Porosity $(\varphi)$ is a function of $\rho_{e}$ and $\rho_{s}$ :

$$
\varphi=\frac{v_{e}-v_{s}}{v_{e}}=1-\frac{m / \rho_{s}}{m / \rho_{e}}=1-\frac{\rho_{e}}{\rho_{s}}
$$

$v_{e}$ and $v_{s}=$ envelope and skeletal volume and $m=$ mass. 
171

172

173

174

175

176

177

178

179

180

181

182

183

184

185

186

187

188

189

190

191

192

193

194

195

\subsection{Imbibition assay}

We compared aged biochar recovered from the $30 \mathrm{tha}^{-1}$ plots with fresh biochar particles. Samples were treated as described earlier and three pairs of fragments with similar weight $( \pm 0.04 \mathrm{mg})$ and shape were selected, rinsed (DI- $\left.\mathrm{H}_{2} \mathrm{O}\right)$, and oven-dried at $75^{\circ} \mathrm{C}$ for $48 \mathrm{~h}$. The last washing step was repeated 3 times to reduce sample hydrophobicity. Fragments were individually transferred into 75 $\mathrm{mL}$ glass tubes filled with $\mathrm{DI}-\mathrm{H}_{2} \mathrm{O}$ and carefully placed on the water surface, allowing the fragments to float. Tubes were unsealed, never disturbed, and maintained at room temperature, allowing natural water infiltration. We recorded the sinking of each fragment until particles reached the bottom of the tubes. The amount of absorbed water in sunken fragments was determined by massing before and after drying at $105^{\circ} \mathrm{C}(96 \mathrm{~h})$.

\subsection{Biochar chemistry changes following environmental exposure}

\subsection{1 pH and electrical conductivity (EC)}

Oven-dried $\left(105^{\circ} \mathrm{C}\right)$ samples were added to DI- $\mathrm{H}_{2} \mathrm{O}$ at a mass ratio of 1:20 and shaken 90 min at $120 \mathrm{rpm}$ (Rajkovich et al., 2012). pH and EC were measured on the filtered surnatant under continuous stirring by a pH-meter (BasiC 20, Crison, Barcelona, Spain) and a conductimeter (CDM210 Conductivity Meter, Radiometer Analytical, Copenhagen, DK).

\subsubsection{Total $C, N$ and $H$ content}

We sampled $3 \mathrm{mg}$ of ground biochar for total $\mathrm{N}$ and $\mathrm{H}$ and $0.1 \mathrm{mg}$ for $\mathrm{C}$ determination by catalytic combustion (ECS 4010, Costech Analytical Technologies Inc.; Valencia, CA).

\subsection{3 $\mathrm{KCl}$ extractable $\mathrm{NO}_{3}^{-}-\mathrm{N}$ and $\mathrm{NH}_{4}^{+}-\mathrm{N}$}

We extracted intact oven-dried biochar fragments using a $2 \mathrm{M} \mathrm{KCl}$ solution at a ratio of 1:20 ( $\mathrm{w} \mathrm{w}^{-}$ ${ }^{1}$ ). Samples were shaken for $90 \mathrm{~min}$ at $100 \mathrm{rpm}$ by an orbital shaker and the filtered (Whatman 42 ) 
surnatant was analyzed by a continuous flow autoanalyzer (AA-3, Bran+Luebbe, Norderstadt, Germany).

\subsubsection{Biochar surface atomic composition}

We analyzed three fragments per replicate by XPS for relative $\mathrm{C}, \mathrm{O}, \mathrm{Si}, \mathrm{N}, \mathrm{Na}, \mathrm{Al}, \mathrm{Mg}, \mathrm{P}, \mathrm{K}, \mathrm{Ca}$, $\mathrm{Mn}$, and Fe atomic composition (at\%) in the top $5 \mathrm{~nm}$ (Fig. 1) using a PHI Quantera XPS with a focused monochromatic $\mathrm{Al} \mathrm{K \alpha}$ X-ray source for excitation at $1486.6 \mathrm{eV}$ and $49.2 \mathrm{~W}$. We performed high-resolution, low-intensity scans to focus on the $\mathrm{C}$ bonding environments with 40 scans. XPS spectra were analyzed using a nonlinear, least-squares curve-fitting program with a Gaussian-Lorentzian mixed function to optimize the spectra using MultiPak data analysis software (MultiPak V7.0.1, Ulvac-Phi, Inc.).

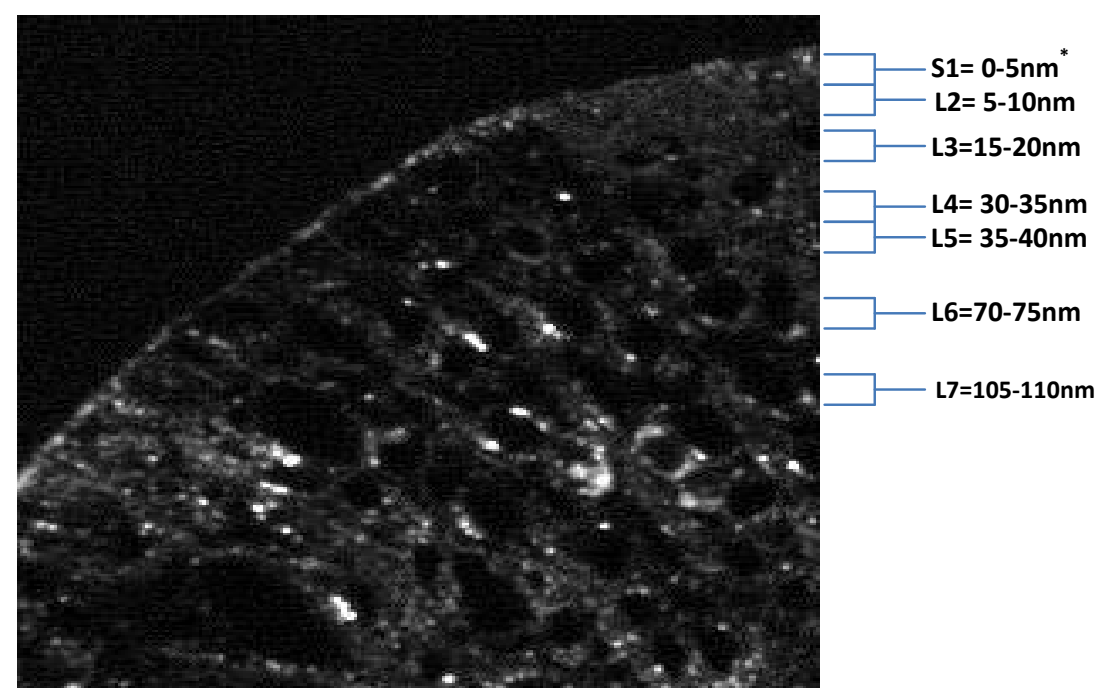

Figure 1. The biochar profiles scanned by X-ray photoelectron spectroscopy (XPS). Magnification obtained by a Zeiss SteREO Discovery.V20 microscope

*Depths are not strictly to scale

\subsubsection{Biochar inner layer at\%}

We compared fresh and aged (from $30 \mathrm{t} \mathrm{ha}^{-1}$ plots) biochar fragments (4 replicates) for relative $\mathrm{C}$, $\mathrm{O}, \mathrm{Si}, \mathrm{N}$, and $\mathrm{Al}$ at $\%$ at four depths $(\mathrm{S} 1=0-5 \mathrm{~nm}, \mathrm{~L} 2=5-10 \mathrm{~nm}, \mathrm{~L} 3=15-20 \mathrm{~nm}$ and $\mathrm{L} 4=30-35 \mathrm{~nm}$; Fig. $1)$. 
Three additional fragments of fresh and aged biochars were used to determine the relative $\mathrm{C}, \mathrm{O}, \mathrm{Si}$, $\mathrm{N}$, and $\mathrm{Al}$ at $\%$ at additional depths $(\mathrm{S} 1=0-5 \mathrm{~nm}, \mathrm{~L} 5=35-40 \mathrm{~nm}, \mathrm{~L} 6=70-75 \mathrm{~nm}$ and $\mathrm{L} 7=105-110 \mathrm{~nm}$; Fig. 1).

We calibrated the XPS assessing the etching depth by using a standard $100 \mathrm{~nm}$ tick of $\mathrm{SiO}_{2}$ as a reference. The relative etching rate for C-containing compounds was extrapolated by a computer simulation (based on the exact etching rate for $\mathrm{SiO}_{2}$ ) as compared with a spreadsheet provided by the manufacturer.

We deconvoluted the $\mathrm{C} 1 \mathrm{~s}$ region bonding state into component functional groups. The $-\mathrm{C}-\mathrm{C} /-\mathrm{C}-\mathrm{H} /-$ $\mathrm{C}=\mathrm{C}$ bonds exhibit the same binding energy $(284.74 \mathrm{eV})$ and thus were considered together, while $\mathrm{C}-\mathrm{O},-\mathrm{C}=\mathrm{O}$ and $-\mathrm{COOH}$ were targeted at $285.95,287.18$ and $288.56 \mathrm{eV}$.

\section{Statistical Analyses}

Data were evaluated according to a randomized block design with 5 replicates. Data of XPS analyses at different fragment depths were evaluated as a factorial randomized block design with 2 factors: biochar age (2 levels) and layer (4 levels). When ANOVA showed statistical effects ( $p \leq$ 0.05), means were separated by Student-Newman-Keuls Test; when interaction between factors was significant, 2 times standard error of means was used as the minimum difference between two statistically different means (Saville and Rowarth, 2008). Data of the imbibition assay were submitted to repeated measures analysis of variance using PROC MIXED (Little et al., 1998) in SAS 9.0 (SAS Institute Inc. Cary, NC, USA), with the fragment weight as covariant and a compound symmetry covariance structure.

\section{Results and Discussion}

\subsection{Biochar physical properties as affected by environmental exposure}




\subsubsection{Density and Porosity}

Field exposure induced the most significant physical changes in biochar $\rho_{\mathrm{s}}$ and $\rho_{\mathrm{e}}$, which increased by 160 and $15 \mathrm{mg} \mathrm{cm}^{-3}$, respectively (Fig. 2).

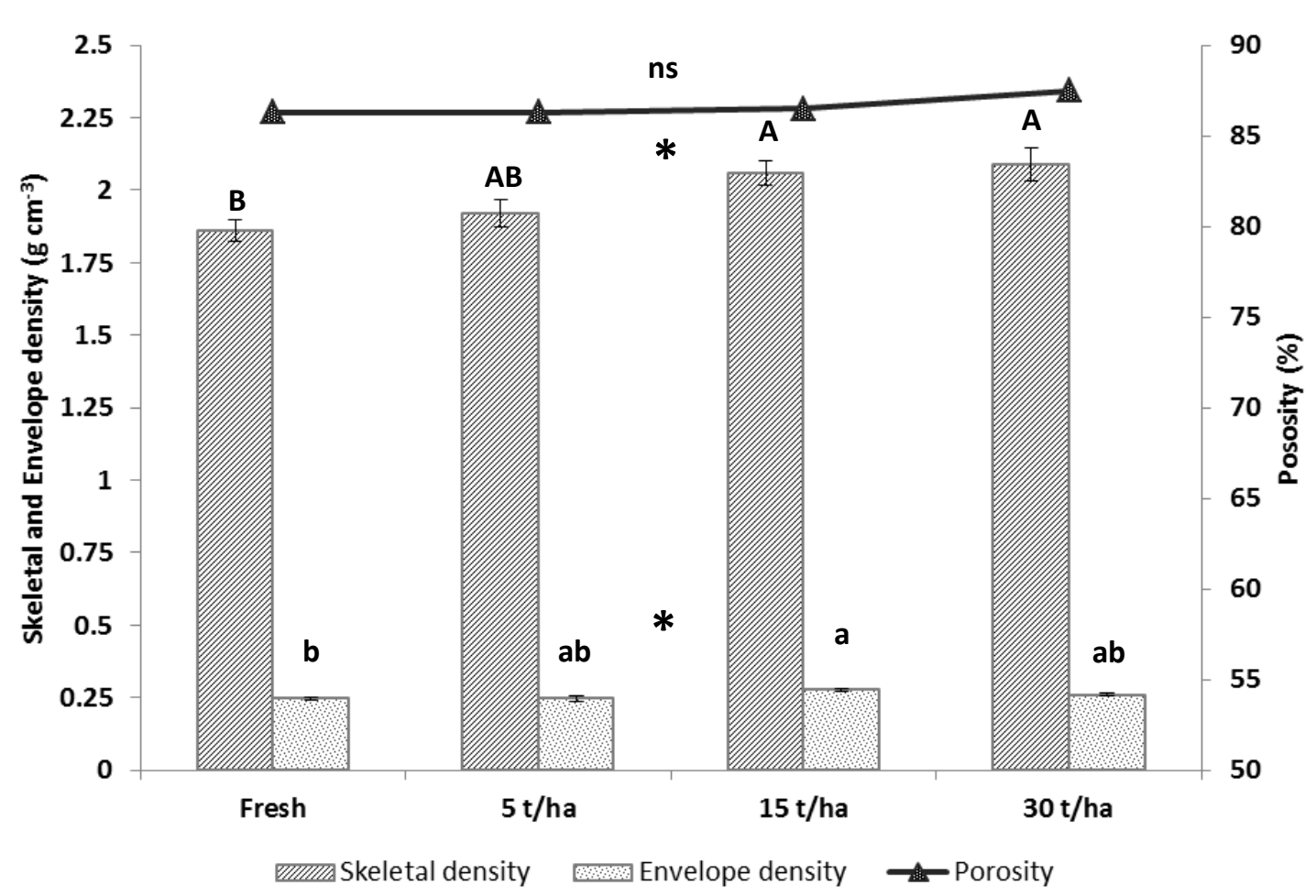

Figure 2. Effect of environmental exposure (4 years in field conditions) on density (skeletal and envelope) and porosity of biochar fragments (avg. $\pm \mathrm{SE} n=5$ ) applied at different rates as compared with fresh biochar.

ns and $*=$ effect of biochar ageing and rate not significant or significant at $p \leq 0.05$. Bars with the same letter are not statistically different $(p \leq 0.05)$ according to the Student-Newman-Keuls (SNK) test.

This increase in $\rho_{\mathrm{s}}$ may be due to biochar particle breakage and mechanical stresses (e.g. freezethaw cycles) as recently evidenced by Spokas et al. (2014) who reported cracks and fractures (physical disintegration) on biochar surfaces induced by water and soil exposure. This breakage may increase pore connectivity by i) connecting previously isolated pores and ii) opening externally connected pores which may represent entry points for denser minerals that may fill or partially fill 
previously empty spaces. Similarly, capillary forces may also drive the soil solution into biochar

271 pores since plant-derived biochars have a high concentration of macropores $(>50 \mathrm{~nm})$ (Downie et

272 al., 2009), which are much larger than a water molecule $(0.28 \mathrm{~nm})$. Flowing water can carry small

273 particles in suspension (including small biochar fragments) into biochar micropores; these particles

274 may accumulate and/or clog in the pore channels (Joseph et al., 2010). Charred and non-charred

275 compounds may remain physically blocked or chemically attracted within particles, altering pore

276 connectivity (Jaafar et al., 2014; Joseph et al., 2010).

277 Recent studies support the rationale that soil particles (e.g. colloidal, dissolved, soluble inorganic

278 salts and/or aluminosilicates) can fill exposed cavities of soil-exposed biochar fragments (Spokas et

279 al., 2013; 2014).

280 Our microscopic images (Fig. 3) support the idea that interactions with minerals and/or microbes 281 change the biochar's physical properties (Jaafar et al., 2014; Brodowski et al., 2006; Liang et al., 282 2006; Warnock et al., 2007; Hockaday et al., 2006) In our images minerals partially fill biochar 283 fractures, starting from the particle's outer edges. Newly inaccessible volumes may be occupied by 284 a combination of trapped water and/or air, leading to porosities that vary with water exposure 285 history. 

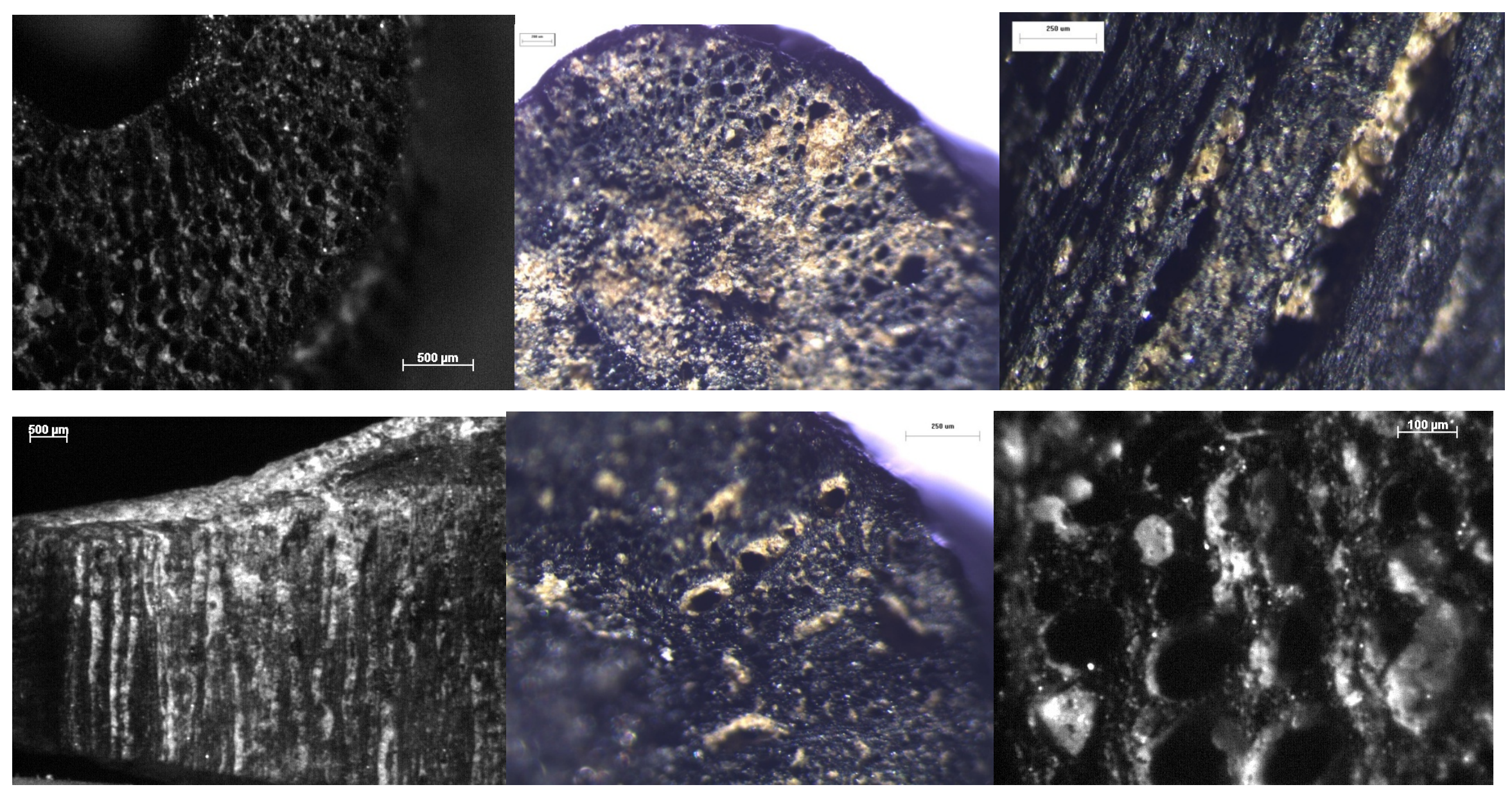

Figure 3. Magnification of biochar fragments recovered from a nectarine orchard after 4 years of environmental exposure. Minerals and soil particles are adhering and/or are physically trapped over the entire particle surface. Pores appear partially or totally blocked by soil particles, likely reducing accessibility. Color magnifications were obtained by an Olympus SXZ16 microscope coupled with an Olympus digital camera whereas the others

were obtained

by

a Zeiss

SteREO

Discovery.V20 microscope. 


\subsubsection{Ageing reduced the rate of water imbibition}

Biochar pores have been classified as surface-site pores ( $\alpha$-type) and bulk-site pores ( $\beta$-types)

(Clarkson et al., 1998). As biochar become water-filled, diffusional processes allow the transition of water between the $\alpha$-type and $\beta$-type pores. However, physical (pore size) and/or chemical (solidliquid interactions) factors may interfere with water movement within biochar particles (Clarkson et al., 1998; Conte et al., 2013). When biochar pores totally or partially clog, water flow into and out of particles becomes physically hampered, hence water infiltration rate likely changes. In our biochar imbibition assay, fresh biochar sank faster than aged particles. Fresh biochar samples started to sink after $156 \mathrm{~h}$ and completely settled between 162 and $168 \mathrm{~h}$ while aged samples started sinking between 168 and $180 \mathrm{~h}$, settling slowly up to $268 \mathrm{~h}$, then accelerated until reaching the bottom of the tubes near $276 \mathrm{~h}$ (Fig. 4). The ratio of water:biochar $\left(\mathrm{w} \mathrm{w}^{-1}\right)$ of the sunken fragments was unaffected by ageing and values were $4.98( \pm 0.30)$ and $5.16( \pm 0.35)$ for fresh and aged fragments, respectively. These results suggest that pore openings are becoming partially clogged, but not filled with solid materials.

However, as mentioned above, chemical factors may also interfere in the biochar-water relationship. This, in turn, refers to the development of $\mathrm{H}$ bonds between the water-derived $\mathrm{O}$ and $\mathrm{H}$ atoms of the biochar aromatic systems (Clarkson et al., 1998). The last interaction was elucidated by Conte et al. (2013), who suggested that water molecules may be bound to the solid carbonaceous material through non-conventional $\mathrm{H}$ bonds. As ageing induces the development of $\mathrm{O}-$ and $\mathrm{H}-$ containing functional groups onto the biochar surface, as a consequence of surface oxidation (Zimmerman, 2010), the last biochar-water mechanism results promoted in aged biochar with implications on the water mobility.

It seems also reasonable to hypothesize a similar reverse sense (pore drainage), with aged biochar fragments retaining water longer. In this case, and assuming water-saturated particles, the partial blocking of biochar pores may allow biochar-amended soils to hold water longer between rainfall events. 


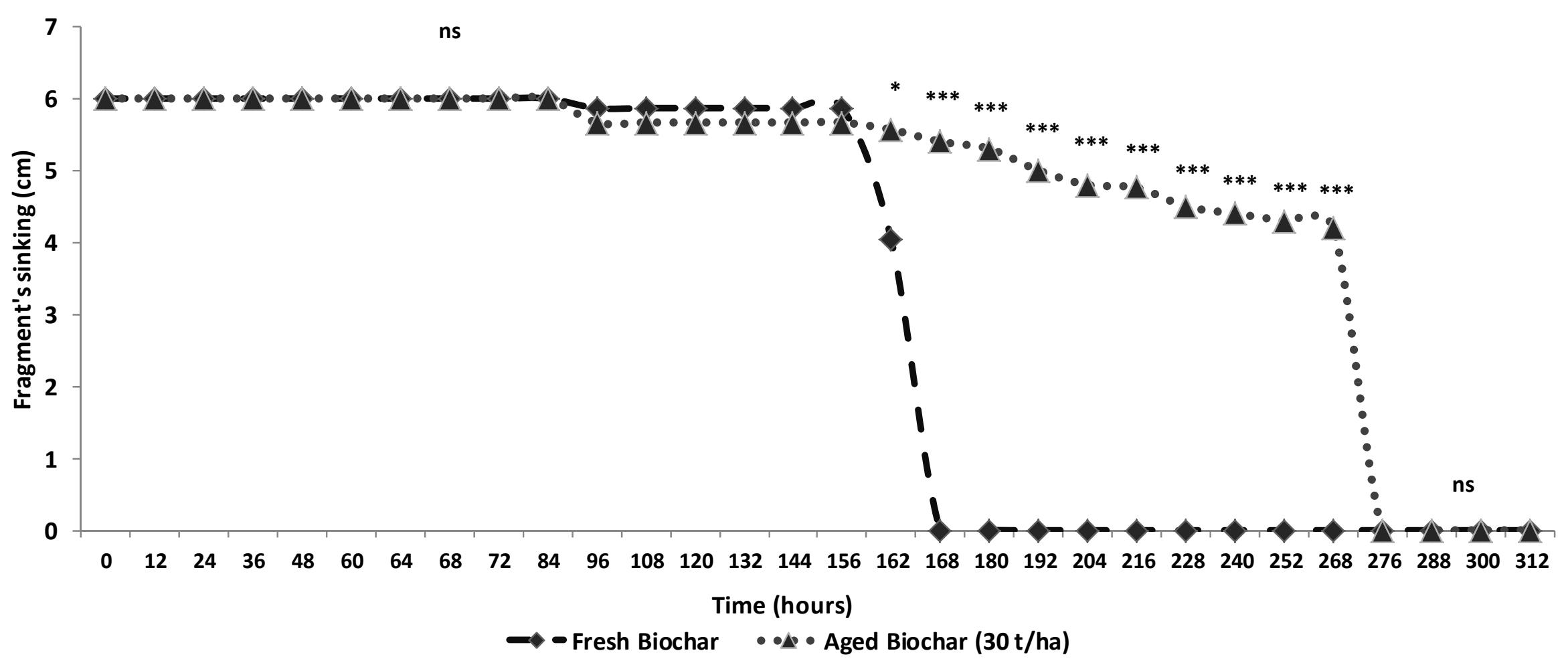

320 Figure 4. Sinking dynamics of fresh vs. aged (4 years in field conditions at the rate of $\left.30 \mathrm{t} \mathrm{ha}^{-1}\right)$ biochar fragments $(\mathrm{n}=3)$

$321 \mathrm{~ns},{ }^{*}$ and $* * *=$ effect not significant or significant at $p \leq 0.05$ and $p \leq 0.001$, respectively. 
4.2 Biochar chemistry changes as affected by the environmental exposure

4.2.1 pH, EC, total elemental $\mathrm{C}, \mathrm{N}, \mathrm{H}$, extractable $\mathrm{NO}_{3}{ }^{-} \mathrm{N}$ and $\mathrm{NH}_{4}{ }^{+}-\mathrm{N}$ concentration

Ageing decreased biochar $\mathrm{pH}$ and increased EC (Tab. 1).

Table 1. $\mathrm{pH}$, electrical conductivity $(\mathrm{EC})$, total $\mathrm{C}, \mathrm{H}, \mathrm{N}$ concentration and $\mathrm{KCl}$ extractable $\mathrm{NO}_{3}-\mathrm{N}$ and $\mathrm{NH}_{4}-\mathrm{N}$ of different rates of aged as compared with fresh biochar fragments

\begin{tabular}{|c|c|c|c|c|c|c|c|}
\hline Biochar & $\mathbf{p H}$ & EC & $\mathrm{C}$ & $\mathbf{H}$ & $\mathbf{N}$ & $\mathrm{NO}_{3}{ }^{-}-\mathrm{N}$ & $\mathrm{NH}_{4}{ }^{+}-\mathrm{N}$ \\
\hline & & $\mu \mathrm{S}$ & g $100 g^{-1}$ & g $100 g^{-1}$ & g $100 g^{-1}$ & $\mathrm{mg} \mathrm{kg}^{-1}$ & $\mathrm{mg} \mathrm{kg}^{-1}$ \\
\hline Fresh & $9.97 a$ & 903.5a & 77.6a & 1.41 & $0.23 c$ & $5.51 \mathrm{~b}$ & $132.3 \mathrm{~b}$ \\
\hline Aged 5 t ha-1 & 7.81b & $129.8 \mathrm{~b}$ & $66.7 \mathrm{~b}$ & 1.48 & $0.92 a$ & 82.5 a & 248.8 a \\
\hline Aged $15 \mathrm{t} \mathrm{ha}^{-1}$ & $8.09 b$ & $144.8 \mathrm{~b}$ & $66.3 b$ & 1.40 & $0.73 b$ & 69.2 a & 230.9 a \\
\hline Aged 30 t ha $^{-1}$ & 8.08b & $158.2 b$ & $66.1 \mathrm{~b}$ & 1.21 & $0.97 a$ & $83.4 \mathrm{a}$ & 342.7 a \\
\hline Significance & $* * *$ & $* * *$ & $*$ & ns & $* * *$ & $* * *$ & $* *$ \\
\hline
\end{tabular}
column, means followed by the same letter are not statistically different $(p<0.05$, SNK Test)

The weathering-induced carboxylic acids functional groups lead to a decrease of basic sites on the biochar surface (Quian et al., 2014; Yao et al., 2010; Cheng et al., 2009), explaining the significant reduction of $\mathrm{pH}$ ( $\sim 2$ units) in aged biochar. This suggests that biochar liming potential is be limited to few years after its application. Hence, biochar-induced benefits in nutrient availability in acid soils may be more pronounced in the first seasons following application. Similarly, the undesirable further $\mathrm{pH}$ increase in alkaline soils due to biochar application may be transient.

Total C concentration was reduced by $14.5 \%( \pm 0.18)$ by ageing, irrespective of the application rate (Tab. 1). The last response is partly due to mineralization of the labile $\mathrm{C}$-fraction associated with biochar (Norwood et al., 2013). This mineralization may occur through the loss of volatile organic compounds generated during pyrolysis and condensed during cooling (Rajkovich et al., 2012) which are more reactive than the aromatic fractions (Joseph et al., 2010). This leads to an initial evolution of biochar-derived $\mathrm{CO}_{2}$ in soils after its application (few months), partly attributed to biochar surface oxidation (Bruun et al., 2008; Steiner et al., 2008). 
Finally, a fraction of biochar-derived C was likely lost through leaching of dissolved organic C (DOC). Mukherjee and Zimmerman (2013), for instance, measured a significantly higher DOC in the soil leachate amended with two different biochars obtained at two pyrolysis temperatures. The additional rate of DOC in the leachate was unambiguously biochar-derived, as shown by the increase in the aromaticity of the DOC measured in the biochar-amended soil leachate (Barnes et al., 2014)

However, the $14 \%$ reduction of total $\mathrm{C}$ concentration in biochar fragments after 4 years soil incubation appear higher compared to mean averages reported in literature (Lehmann et al., 2009; Kuzyakov, et al., 2014) To this regard, it must be mentioned that at the time of soil application, biochar was freshly produced thereby its content of water-soluble C-containing compounds was abundant, likely promoted also by the relatively low $\max \mathrm{T}^{\circ}\left(550^{\circ} \mathrm{C}\right)$ reached during pyrolysis. In addition, a dilution effect induced by the attachment of organo-mineral complexes on the aged biochar surfaces is also reasonable, consistent with the increase of both the $\mathrm{N}_{\text {org }}$ and $\mathrm{N}_{\min }$ fractions measured on the aged fragments. This last mechanism was recently proposed by Kammann et al. (2015) to explain $\mathrm{NO}_{3}-\mathrm{N}$ capture on/in the porous biochar structure, encompassing with the development of acid and basic functional groups (as we also observed in our study) as well as the development of unconventional H-bonding.

Total $\mathrm{N}$ concentration increased in aged biochars by 3.8 fold, irrespective of application rate. Such increase was more pronounced when biochar was applied at $5 \mathrm{t} \mathrm{ha}^{-1}$ (4.0 fold) and $30 \mathrm{t} \mathrm{ha}^{-1}$ (4.2 fold) (Tab. 1). The most significant contribution to the total $\mathrm{N}$ increase was due to the organic $\mathrm{N}$ forms, which were $56 \%$ of the total N, on average. Similarly, Joseph et al. (2010) reported an increase in the $\mathrm{N}$ content of two different biochars mainly associated with proteins, amino acids, $\mathrm{NH}_{4}{ }^{+}$and $\mathrm{N}-$ C compounds.

Likewise, extractable inorganic $\mathrm{N}$ increased in aged biochar, and $\mathrm{NO}_{3}{ }^{-}$and $\mathrm{NH}_{4}{ }^{+}$concentrations were significantly higher in aged than in fresh biochar, confirming the potential of charred biomasses in $\mathrm{N}$ retention and reduction in N-containing GHGs emission in soils (Spokas et al., 
2012). However, recent evidences suggest that standard analytical methods (as adopted in our study) could not detect all biochar-bound nutrients, in particular nitrate-N, which may then remain frequently underestimated (Kammann et al., 2015). However, although the absolute total value we measured may be underestimated, the nitrate-N extracted from aged biochar $\left(78.3 \mathrm{mg} \mathrm{kg}^{-1}\right)$ was 14 times higher than fresh biochar $\left(5.5 \mathrm{mg} \mathrm{kg}^{-1}\right)$, and unlikely the total nitrate- $\mathrm{N}$ content of fresh biochar, would result higher than aged particles. Besides, Kammann et al. (2015) report that the non-detectable $\mathrm{NO}_{3}-\mathrm{N}$ remains non-exchangeable and captured onto biochar particles, thereby we conclude that such portion is not available to plants.

\subsubsection{Biochar $C$ and $N$ behave differently as it ages in soil}

Consistent with the total biochar C content (Tab. 1), XPS analyses showed that environmental exposure significantly reduced biochar $\mathrm{C}$ at\% (Tab. 2, Tab.3 and Fig. 5).

Table 2. Elemental composition (atomic concentration - at\%) of aged (4-year in field conditions at $30 \mathrm{th}^{-1}$ ) biochar surface (S1) and 3 depths (L2, L3 and L4) compared with fresh biochar as determined by XPS.

\begin{tabular}{|c|c|c|c|c|c|c|c|c|}
\hline & C & \multicolumn{4}{|c|}{$N$} & \multirow[t]{2}{*}{0} & \multirow[t]{2}{*}{ Al } & \multirow[t]{2}{*}{ Si } \\
\hline AGEING & & $\begin{array}{c}\text { S1 } \\
(0-5 \mathrm{~nm})\end{array}$ & $\begin{array}{c}\mathrm{L2} \\
(6-10 \\
\mathrm{nm})\end{array}$ & $\begin{array}{c}\mathrm{L3} \\
(15-20 \\
\mathrm{nm})\end{array}$ & $\begin{array}{c}\mathrm{L} 4 \\
(30- \\
35 \mathrm{~nm})\end{array}$ & & & \\
\hline Fresh & 91.6 & 1.2 & 0.89 & 0.85 & 0.76 & 6.7 & 0.29 & 0.47 \\
\hline Aged & 55.3 & 3.15 & 1.40 & 1.15 & 1.13 & 32.7 & 3.73 & 6.50 \\
\hline Significance & $* * *$ & \multicolumn{4}{|c|}{ 2SEM $=0.50$} & $* * *$ & $* * *$ & $* * *$ \\
\hline DEPTH & & & & & & & & \\
\hline S1 & 68.74 & & & & & 24.1 & 1.53 & 3.47 \\
\hline L2 & 74.03 & & & & & 19.0 & 2.15 & 3.69 \\
\hline
\end{tabular}


L3

L4

Significance

Interaction Ageing

*Depth
18.2

2.25

3.49

17.6

2.12

3.31

ns

ns

ns

ns

ns

$385 \mathrm{~ns}, * *$ and $* * *=$ effect not significant or significant at $p<0.01$ and $p<0.001$, respectively. Interaction between biochar

386 and layer significant at $p<0.01$. Values differing by $\geq 2$ SEM are statistically differen 


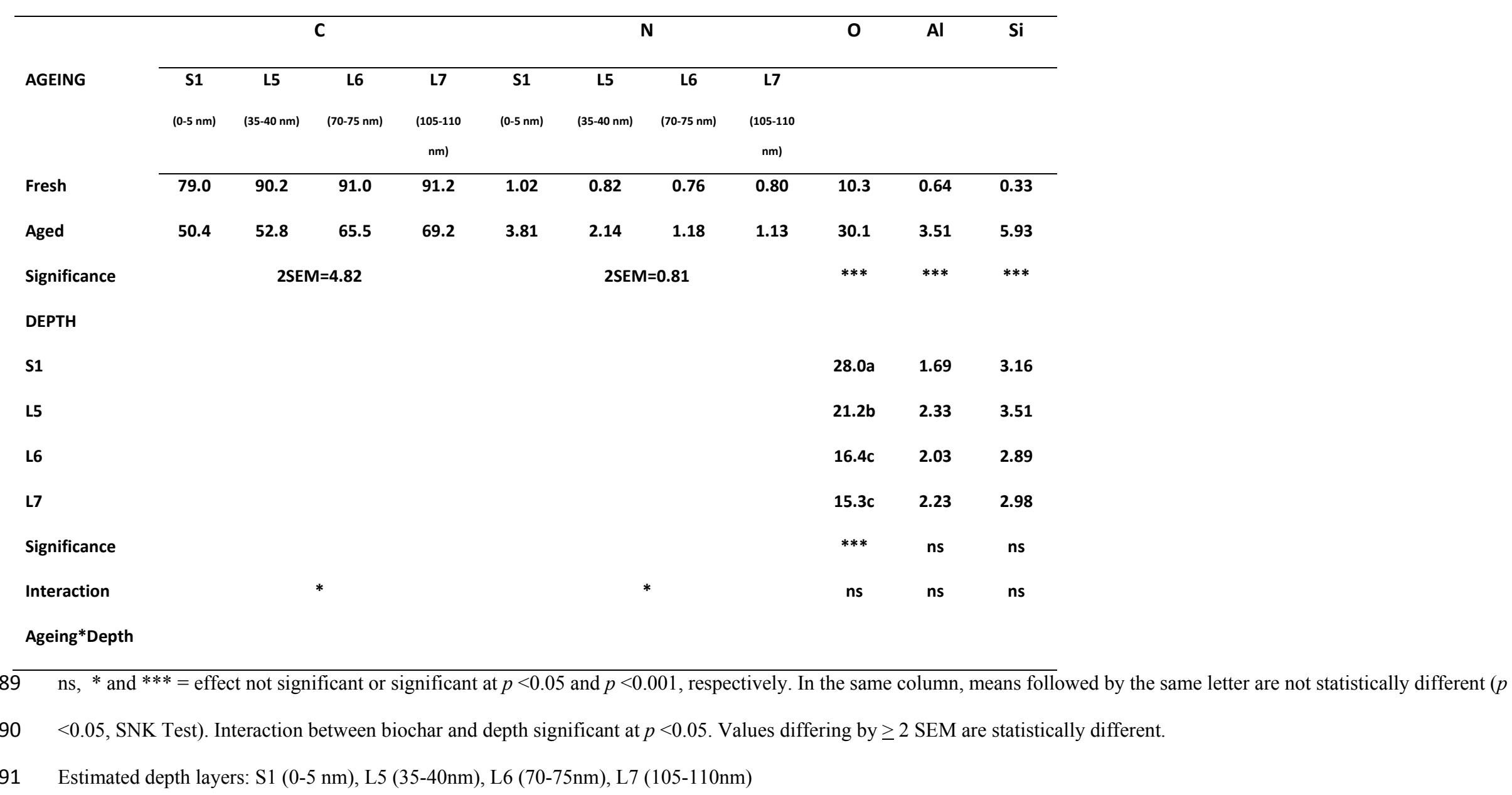



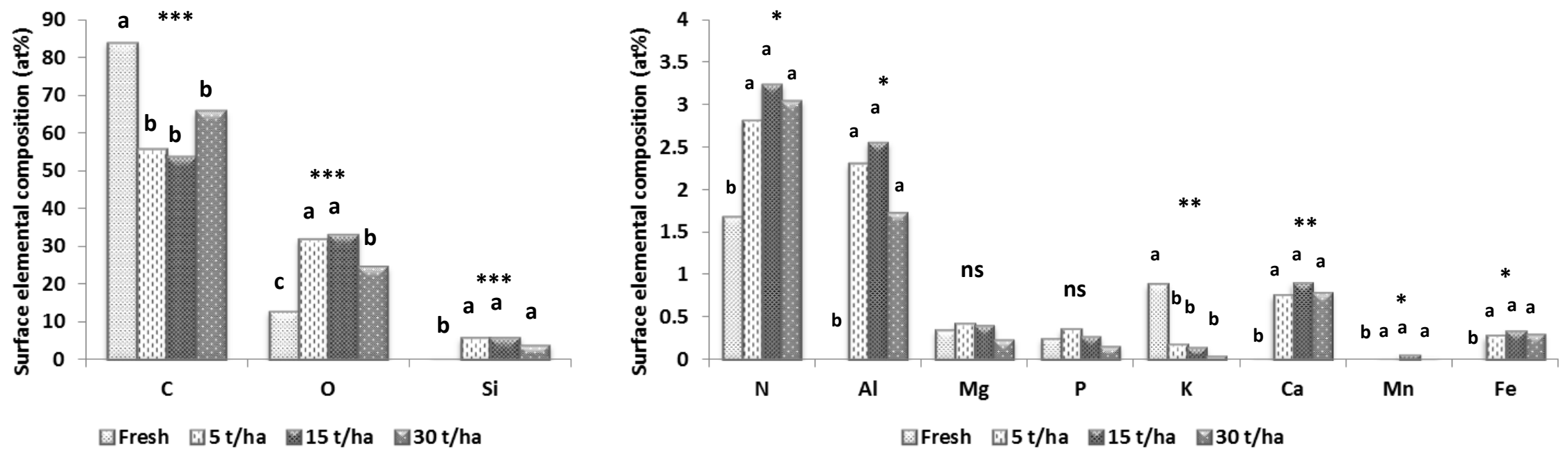

393

Figure 5. Atomic percentage surface elemental composition (XPS) of aged (4 years) biochar applied at different rates as compared with fresh biochar

$\mathrm{ns}, *, * *$ and $* * *=$ effect of biochar ageing and rate not significant and significant at $p \leq 0.05, p \leq 0.01$ and $p \leq 0.001$, respectively. Within each element, bars with the same letter are not statistically different $(p \leq 0.05)$, according to the Student-Newman-Keuls (SNK) test. 
Independent of the application rate, 4 years of field exposure reduced surface $(0-5 \mathrm{~nm})$ biochar relative $\mathrm{C}$ at $\%$ up to $35.5 \%$ compared to unexposed fragments (Fig. 5). The most intense reduction in biochar $\mathrm{C}$ at $\%$ occurred in the top $5 \mathrm{~nm}$ layer either in fresh ($13 \%)$ and aged biochars (-19.4\%) (Tab. 2) as a response to the natural oxidation.

Biochar C depletion was less intense in inner layers and no effects were observed in layers deeper than $35 \mathrm{~nm}$ in fresh particles. Depletion of C occurred up to $70 \mathrm{~nm}$ depth in aged fragments (Tab. 3). Within aged particles, biochar $\mathrm{C}$ at $\%$ vs depth could be fit by a positive regression model according to an exponential trend with a coefficient of determination $\left(\mathrm{R}^{2}\right)$ equal to $0.93\left(\mathrm{y}=44.025 \mathrm{e}^{0.1167 \mathrm{x}}\right)$. These responses suggest that exposure in croplands strongly alters biochar $\mathrm{C}$ surface composition and that $\mathrm{C}$ depletion starts from the top exposed layer and proceed toward the interior, as a consequence of both biotic and abiotic oxidation. In our experiment after 4 years biochar's relative $\mathrm{C}$ content was reduced by $\sim 15 \%$ compared to its initial values. This relative reduction in $\mathrm{C}$ content could be due to loss of biochar $\mathrm{C}$, or it could simply be the result of increased contents of other atoms relative to C (Tab. 2, Tab. 3), as mentioned above. Regardless, the amount of labile $\mathrm{C}$ lost compared to stable $\mathrm{C}$ stored in soils with biochar is still considered comparatively negligible and should not affect the $\mathrm{C}$ sequestration potential of biochar on a long-term basis (Joseph et al., 2010). As expected, relative $\mathrm{N}$ at\% was unaffected within layers of fresh particles (Tab. 2 and Tab. 3). Total $\mathrm{N}$ concentration (Tab. 1) and $\mathrm{N}$ at\% (Tab. 2, Tab. 3 and Fig. 5) was statistically higher in aged fragments, showing the opposite trend compared to C. In aged fragments, biochar $\mathrm{N}$ at $\%$ was statistically higher mostly in the top surface (Fig. 5, Tab. 2 and Tab. 3), up to $40 \mathrm{~nm}$ depth (Tab. 3). Ageing and depth significantly interacted with atomic $\mathrm{N}$ composition and it decreased progressively within aged 
422 fragments as the depth increased up to $75 \mathrm{~nm}$ depth (L6), while no differences were 423 recorded between the deepest (L6 and L7) layers (Tab. 3). This evidence suggests that

424 mechanisms for $\mathrm{N}$ retention in aged biochar occur mainly in the exposed top surface,

425 but are not only limited to this. Furthermore, the $\mathrm{C} / \mathrm{N}$ ratio of the biochar fragments

426 dramatically decreases as biochar ages, with potential implications for processes that are

$427 \mathrm{C} / \mathrm{N}$-influenced (e.g. microbial activity).

\subsubsection{Environmental exposure alters biochar surface $\mathrm{K}, \mathrm{Ca}, \mathrm{Mn}$ and $\mathrm{Fe}$ ratio}

430 Ageing significantly affected the biochar surface relative at $\%$ of $\mathrm{K}, \mathrm{Ca}, \mathrm{Mn}$ and Fe with no effects induced by the application rate (Fig. 5). No differences were detected for $\mathrm{Mg}$ and $\mathrm{P}$ at $\%$. Surface relative $\mathrm{K}$ at $\%$ of aged biochar was reduced compared to fresh biochar up to 29.3 fold for the 30 t/ha application rate (Fig. 5). On the contrary, surface at $\%$ of $\mathrm{Ca}, \mathrm{Mn}$, and Fe were higher in aged fragments, with no effects induced by the application rate (Fig. 5). The most abundant increase was measured for $\mathrm{Ca}$ which increased by 90 fold while $\mathrm{Mn}$ at\% recorded a limited increase, although significant. It

437 is worth mentioning that these changes are expressed as relative at $\%$, which estimate the 438 relative atomic abundance ratio among scanned elements instead of giving the absolute 439 concentration. Biochar surface ageing-induced effects can be ascribed either to physical 440 or chemical mechanisms. The surface of the weathered biochar particles was finely 441 coated with soil and organic residues which appeared to adhere and/or be trapped in 442 pores and fractures, partially explaining the higher concentration for most of the 443 elements found on the biochar surface. Chemical mechanisms involved the high reactive 444 charge density of the biochar surface (Van Zwieten et al., 2010), which has adsorption 445 sites where cations, clay, and organic matter may be ionically or covalently bound, 
446 confirming the interaction of biochar with minerals and organic compounds in soils.

447 This may also contribute to explaining the higher values of $\mathrm{O}$ at $\%$ recorded in aged

448 fragments (Fig. 5). The potential of biochar to retain minerals directly on its surface

449 (Glaser et al., 2002) increases the ability of biochar to retain nutrients in soils. Various

450 combinations of $\mathrm{Al}, \mathrm{Si}, \mathrm{C}, \mathrm{Fe}$, and $\mathrm{Ti}$, and trace amounts of $\mathrm{Ca}, \mathrm{Mg}, \mathrm{Mn}, \mathrm{K}, \mathrm{Na}, \mathrm{P}$, and

451 S were found at the external surfaces of aged greenwaste biochar particles (Joseph et al.,

452 2010). However, the lack of change in the $\mathrm{P}$ and $\mathrm{Mg}$ atomic surface composition found

453 in this study indicates that this process is biochar-type and soil dependent. Different

454 processes (dissolution, hydrolysis, carbonation, decarbonation, hydration, redox

455 reactions) and several mechanisms (H-bonding, cation-bridging, covalent bonding and

456 hydrophobic types of interactions) are involved in biochar weathering processes as a

457 consequence of its interactions with OM, water, adsorption of dissolved organic (e.g.

458 root exudates) and inorganic compounds and oxidation (Joseph et al., 2010). In

459 particular, the significant decrease of $\mathrm{K}$ at $\%$ in aged biochar surfaces we observed $(87 \%$

460 in average relative to the fresh particles) may be due to the dissolution of soluble salts

461 and organic compounds (i.e. biopolymers and low molecular weight compounds)

462 associated with charred particles which is among the first reactions upon biochar

463 addition to soil (Joseph et al., 2010; Shinogi et al., 2003). This is also confirmed by the

464 reduced EC that we measured in aged particles. The dissolution process may induce a

465 rapid increase in the availability of water soluble cations in the soil layer, where biochar

466 is incorporated, thus when high rates are applied, biochar may represent a consistent

467 source of $\mathrm{K}$, enough to fulfill plant requirement (according to the application rate,

468 biochar type and crop) for the first 2-3 seasons after its incorporation. However, results

469 from a column experiment showed that weathering reduced not only the content of $\mathrm{K}$ 
472

473

474

475

476

477

478

479

480

481

but also S, Ca, and P (Yao et al., 2010), suggesting that mineral release from charred materials is controlled by biochar characteristics and the environment.

\subsubsection{Ageing promotes biochar oxidation, Al and Si at\%}

Although chemically induced biochar degradation starts before incorporation in soil as a result of the oxidation of exposed $\mathrm{C}$ rings with a high density of $\pi$-electrons (Contescu et al., 1998) and free radicals (Montes- Morán et al., 2004), only once in soil does biochar experience significant chemical weathering. In our experiment, ageing increased values of biochar $\mathrm{O}, \mathrm{Al}$, and $\mathrm{Si}$ at\% (Fig. 5, Tab. 2). Ageing and depth did not interact in atomic $\mathrm{O}, \mathrm{Al}$, and $\mathrm{Si}$ composition and values of biochar $\mathrm{O}, \mathrm{Al}$, and $\mathrm{Si}$ at\%, were comparable among layers (Tab. 2 and Tab. 3). Nevertheless, depth affected atomic O composition, which was reduced as the depth increased (Tab. 3). Independently of the layer, values of $\mathrm{O}, \mathrm{Al}$, and $\mathrm{Si}$ always increased in aged biochar by 3, 5, and 18 fold, respectively (Tab. 3). Environmental exposure promoted fragment's oxidation (Tab. 2 and 3) and, independent of the age, oxidation started from the top exposed surface and was progressively reduced as depth increased down to $75 \mathrm{~nm}$ (Tab. 3), likely as a result of both biotic and abiotic processes, although some research suggests that biotic processes dominate (Zimmerman , 2010; Cheng et al., 2006). The O:C ratio of our biochar surface shifted from $<0.074$ to $>0.58$ after 4 years in field conditions as a consequence of the depletion of $\mathrm{C}$ and increase of $\mathrm{O}$ content. This may have consequences for biochar stability in soil, since the increase of the $\mathrm{O}: \mathrm{C}$ ratio has been cited as a fundamental attribute in controlling the resistance to microbial mineralization (Harvey et al., 2012; Spokas et al., 2010;), although it may also simply reflect the 
increased $\mathrm{O}$ present in soil minerals and/or dissolved organic matter that have attached

494 to the biochar.

495

496

\subsubsection{Oxidation affects biochar C functional groups}

497 Our results show that biochar C functional groups were affected by the interaction

498 between ageing and depth (Tab. 4). The relative at $\%$ of the $\mathrm{C}$ functional groups always

499 increased by ageing in the top 3 layers (S1+L5+L6 layers, equal to $0-75 \mathrm{~nm}$ depth)

500 (Tab. 4), except for the $-\mathrm{C}-\mathrm{C} /-\mathrm{C}-\mathrm{H} /-\mathrm{C}=\mathrm{C}$ bonds, where only in the top surface an

501 opposite trend was recorded (Tab. 4). No differences were measured in the deepest layer

$502(105-110 \mathrm{~nm})$ between fresh and aged biochars (Tab. 4). The overall development of C

503 functional groups $(-\mathrm{C}=\mathrm{O},-\mathrm{C}-\mathrm{O},-\mathrm{COOH})$ on the aged biochar surface as a consequence

504 of the natural oxidation which involves the increase in $\mathrm{O}$ and $\mathrm{H}$ composition (Cheng et

505 al. 2008; Yao et al. 2010; Jones et al. 2012; Lin et al. 2012; LeCroy et al. 2013; Qian

506 and Chen, 2014) This oxidation is attributed to both biotic and abiotic processes,

507 although some data suggest that biotic processes dominate (Cheng et al. 2006;

508 Zimmerman, 2010). The increased oxidation of $\mathrm{C}$ in the uppermost surface layers of the

509 aged biochar confirms that oxidation and/or adsorption of soil OM occurred (Joseph et

510 al. 2010). Nevertheless, different functional groups can be formed on aged biochar

511 through oxidation such as lactonic, o-quinone-like structures and ether-type oxygen

512 (Boehm, 2001). In our case, the $-\mathrm{C}-\mathrm{C} /-\mathrm{C}-\mathrm{H} / \mathrm{C}=\mathrm{C}$ bonding state was always the major

513 component of both fresh and aged biochar, although after 4 years the relative

514 composition of these $\mathrm{C}$ bonds significantly decreased only in the top surface.

515 The most significant changes in the $\mathrm{C} 1 \mathrm{~s}$ bonding state were evident on the top surface

$516(0-5 \mathrm{~nm})$, where the relative concentration of $-\mathrm{C}=\mathrm{O},-\mathrm{C}-\mathrm{O}$ and, to a lesser extent, - 
$517 \mathrm{COOH}$, were significantly higher in aged biochar. It is possible that carboxyl functional 518 groups were less developed relative to other oxidized C forms because carboxyl groups 519 may be partially decarboxylated through hydrolysis reactions occurring in solution (Yan 520 et al. 1996). 


\begin{tabular}{|c|c|c|c|c|c|c|c|c|c|c|c|c|c|c|c|c|}
\hline & \multicolumn{16}{|c|}{ Binding Energy (eV) (avg \pm std dev) } \\
\hline & \multicolumn{4}{|c|}{$-\mathrm{C}-\mathrm{C} /-\mathrm{CH} /-\mathrm{C}=\mathrm{C}$} & \multicolumn{4}{|c|}{$-\mathrm{C}-\mathrm{O}$} & \multicolumn{4}{|c|}{$-C=0$} & \multicolumn{4}{|c|}{$-\mathrm{COOH}$} \\
\hline & $284.79 \pm 0.05$ & $284.76 \pm 0.06$ & $284.75 \pm 0.04$ & $284.75 \pm 0.05$ & $286.14 \pm 0.46$ & $285.96 \pm 0.29$ & $285.91 \pm 0.21$ & $285.85 \pm 0.12$ & $287.53 \pm 0.5$ & $286.91 \pm 1.28$ & $287.16 \pm 0.61$ & $287.19 \pm 0.22$ & $288.76 \pm 0.39$ & $288.87 \pm 0.32$ & $288.61 \pm 0.45$ & $288.73 \pm 0.35$ \\
\hline AGEING & S1 & $L 5$ & $L 6$ & $L 7$ & S1 & $L 5$ & $L 6$ & $L 7$ & S1 & $L 5$ & $L 6$ & $L 7$ & S1 & $L 5$ & $L 6$ & $L 7$ \\
\hline Fresh & 75.5 & 67.2 & 65.8 & 65.2 & 13.2 & 23.9 & 24.7 & 25.2 & 5.1 & 5.1 & 5.6 & 5.6 & 6.1 & 3.8 & 3.9 & 4.0 \\
\hline Aged & 51.9 & 79.8 & 78.9 & 73.7 & 27.4 & 15.4 & 16.4 & 18.8 & 12.5 & 3.0 & 3.1 & 4.7 & 8.15 & 1.7 & 1.5 & 2.8 \\
\hline Significance & \multicolumn{4}{|c|}{ 2SEM=8.79 } & \multicolumn{4}{|c|}{ 2SEM=7.35 } & \multicolumn{4}{|c|}{ 2SEM=1.77 } & \multicolumn{4}{|c|}{$2 S E M=1.29$} \\
\hline Interaction & \multicolumn{4}{|c|}{$* *$} & \multicolumn{4}{|c|}{$*$} & \multicolumn{4}{|c|}{$* * *$} & \multicolumn{4}{|c|}{$*$} \\
\hline
\end{tabular}

524 different.

525 Estimated depth layers: S1 (0-5 nm), L5 (35-40nm), L6 (70-75nm), L7 (105-110nm) 
527 Our findings suggest that biochar's effects on soil hydrology may change with time,

528 raising a number of points. It seems reasonable to assume that different soil textures and

529 mineralogies interact differently with various biochars; thus biochar and ecosystem-

530 specific patterns of exterior pore blockage may be expected (Barnes et al., 2014).

531 Furthermore, shifts in soil hydrology pose several implications for water-mediated

532 processes as well as for the erosive fate of applied particles. For instance, soil leaching

533 patterns may be different in aged biochar-mixed soils compared to the immediate

534 response of biochar addition. Likewise, the influence of biochar on water retention may

535 change as biochar ages, in particular in easily drained soils and especially if a dramatic

536 reduction occurs in the number of pores between 0.01 and $0.1 \mathrm{~mm}$. This pore-size range

537 in biochar is fundamental to increased plant available water since larger pores weakly

538 retain water under gravity (Jury et al., 1991) and smaller pores do not provide water in a

539 plant-accessible form (Masiello et al., 2015).

540 Water infiltration shifts the functional density of biochar as water fills internal pores

541 previously occupied by air. Once partially water-filled, the functional density of biochar

542 particles exceeds that of water and the particles sink. The sinking process seems to be

543 altered by field aging, with mineral blockages of pore throats slowing the rate of water

544 infiltration.

545 Similarly, it seems reasonable to hypothesize that it takes longer for aged fragments to

546 dry out. This lag in particle infill time may suggest implications also for the erosion rate

547 of biochar particles.

548 The porous structure of biochar provides suitable habitat for a range of microbial

549 communities (Hockaday et al., 2006; Warnock et al,. 2007; Downie et al., 2009; Thies 
and Rilling, 2009), and fungi can grow from within the pores out into the soil (Lehmann et al., 2011). Pore connectivity has been suggested to modulate the availability of biochar-associated labile organic compounds to microbial enzymes (Barnes et al., 2014). Easier access to these sites in recently added biochar could partially explain the initial high mineralization rates observed after biochar addition (Cross and Sohi, 2011). Our findings suggest potential shifts in microbial colonization patterns as biochar ages in soil. Due to ageing, the attachment of soil particles, changes in pore connectivity and pore clogging of biochar particles may alter habitat suitability and microbial activity (Lehmann et al., 2011; Thies and Rilling, 2009) reducing microbes colonization. However, fractures on the weathering particles may offer new opportunities for microbial colonization. Furthermore, minerals covering the external surface of biochar fragments interfere with its reactive surface, limiting its sorption capacity (Joseph et al., 2010) but at the same time the greater surface reactivity due to oxidation may promote physical protection of biochars and, thus, its long-term stability (Brodowski et al., 2006).

The development of O-containing $\mathrm{C}$ functional groups of aged biochar increases the reactivity of the biochar surface, leading to an enhancement of chemical sites able to retain nutrients and other organic compounds on this surface. This process is also responsible for the evolution of negative charges, raising the biochar CEC over time (Zimmerman, 2010).

These processes occurred mostly on the O-exposed biochar surface, leading to an enhancement of chemical sites able to retain nutrients and other organic compounds on this surface, consistent with the ion sorption pattern of our aged biochar. Oxidized biochar particles may then be bound to soil minerals. Mineral attachment has been 
574 indicated as one of the possible mechanisms for the slowing of biochar decomposition

575 and oxidation (Browdowski et al., 2006; Nguyen et al., 2008), acting as a control on the 576 stabilization process of charred particles.

577

578 Acknowledgments

579 We thank Dr. Xiaodong Gao and Dr. Bo Chen (Rice University, Houston, USA) for

580 their valuable assistance with fragment density determinations and XPS analyses. We

581 appreciated generous laboratory and equipment access provided by Dr. Helge

582 Gonnermann. We also acknowledge funding from the US NSF through grants EAR

5830911685 and 0949337 . Authors thank three anonymous reviews for their valuable

584 comments which helped to improve the manuscript. 
586 Baltrėnas, P., Baltrėnaitè, E., Spudulis, E., 2015. Biochar from Pine and Birch

587 Morphology and Pore Structure Change by Treatment in Biofilter. Water, Air, \& Soil

588 Pollution, 226(3), 1-14.

589

590 Barnes, R. T., Gallagher, M. E., Masiello, C. A., Liu, Z., Dugan, B., 2014. Biochar-

591 Induced Changes in Soil Hydraulic Conductivity and Dissolved Nutrient Fluxes

592 Constrained by Laboratory Experiments. PLoS ONE 9(9), e108340.

593

594 Baronti, S., Vaccari, F. P., Miglietta, F., Calzolari, C., Lugato, E., Orlandini, S., 595 Genesio, L., 2014. Impact of biochar application on plant water relations in Vitis 596 vinifera (L.). Eur. J. Agron. 53, 38-44.

597

598 Bird, M.I., Ascough, P.L., Young, I.M., Wood, C.V., Scott, A.C., 2008. X-ray

599 microtomographic imaging of charcoal. J. Archaeol. Sci. 35(10), 2698-2706.

600

601 Boem, H.P., 2001. Carbon surface chemistry. In Graphite and precursors, Delhaes, P., 602 Eds., CRC: Amsterdam, pp. 141-178.

603

604 Brewer, C.E., Chuang, V.J., Masiello, C.A., Gonnermann, H., Gao, X., Dugan, B., 605 Driver, E.L, Panzacchi, P., Zygourakis, K., Davies, C.A., 2014. New approaches to 606 measuring biochar density and porosity. Biomass Bioenerg. 66, 176-185.

607 
608 Brockhoff, S. R., Christians, N. E., Killorn, R. J., Horton, R., Davis, D.D., 2010.

609 Physical and mineral-nutrition properties of sand-based turfgrass root zones amended

610 with biochar. Agron. J. 102 (6), 1627-1631

611

612 Brodowski, S., John, B., Flessa, H., Amelung, W., 2006. Aggregate-occluded black

613 carbon in soil. Eur. J. Soil Sci. 57(4), 539-546.

614

615 Bruun, S., Jensen, E., Jensen, L., 2008. Microbial mineralization and assimilation of 616 black carbon: Dependency on degree of thermal alteration. Org. Geochem. 39, 839-

617845.

618

619 Bruun, E. W., Petersen, C. T., Hansen, E., Holm, J. K., Hauggaard-Nielsen, H., 2014.

620 Biochar amendment to coarse sandy subsoil improves root growth and increases water

621 retention. Soil Use Manage. 30, 109-118.

622

623 Chen, B., Zhou, D., Zhu, L., 2008. Transitional adsorption and partition of nonpolar and

624 polar aromatic contaminants by biochars of pine needles with different pyrolytic

625 temperatures. Environ. Sci. Technol. 42(14), 5137-5143.

626

627 Cheng, C.H., Lehmann, J., Thies, J. E., Burton, S. D., Engelhard, M.H., 2006. Oxidation

628 of black carbon by biotic and abiotic processes. Org. Geochem. 37, 1477-1488.

629 
630 Cheng, C.H., Lehmann, J., Engelhard, M.H., 2008. Natural oxidation of black carbon in 631 soils: Changes in molecular form and surface charge along a climosequence. Geochim. 632 Cosmochim. Ac. 72, 1598-1610.

633

634 Cheng, C.H., Lehmann, J., 2009. Ageing of black carbon along a temperature gradient. 635 Chemosphere 75, 1021-1027.

637 Clarkson, R.B., Odintsov, B.M., Ceroke, P. J., Fruianu, M., Belford, R. L., 1998.

638 Electron paramagnetic resonance and dynamic nuclear polarization of char suspensions:

639 surface science and oximetry. Physics in medicine and biology 43(7), 1907.

640

641 Conte, P., Marsala, V., De Pasquale, C., Bubici, S., Valagussa, M., Pozzi, A., Alonzo, 642 G., 2013. Nature of water-biochar interface interactions. GCB Bioenergy 5(2), 116-121.

643

644 Contescu, A., Vass, M., Contescu, C., Putyera, K., Schwarz, J.A., 1998. Acid buffering 645 capacity of basic carbons revealed by their continuous pK distribution. Carbon 36(3), $646 \quad 247-258$.

648 Cross, A., Sohi, S.P., 2011. The priming potential of biochar products in relation to 649 labile carbon contents and soil organic matter status. Soil Biol. Biochem. 43(10), $650 \quad 2127-2134$

651 
652 Downie, A., Crosky, A., Munroe, P., 2009. Physical Properties of Biochar. In Biochar 653 for environmental management: science and technology, Lehmann, J., Joseph, S., Eds., 654 Earthscan: London 2009, pp13-32.

655

656 Glaser, B., Lehmann, J., Zech, W., 2002. Ameliorating physical and chemical properties 657 of highly weathered soils in the tropics with charcoal - a review. Biol. Fertil. Soils 35, 658 219-230.

659

660 Harvey, O. R., Kuo, L. J., Zimmerman, A. R., Louchouarn, P., Amonette, J. E., Herbert, 661 B. E., 2012. An index-based approach to assessing recalcitrance and soil carbon 662 sequestration potential of engineered black carbons (biochars). Environ. Sci. Technol. $66346,1415-1421$.

664

665 Hockaday, W. C., Grannas, A. M., Kim, S., Hatcher, P.G., 2006. Direct molecular

666 evidence for the degradation and mobility of black carbon in soils from ultrahigh-

667 resolution mass spectral analysis of dissolved organic matter from a fire-impacted forest

668 soil. Org. Geochem. 37(4), 501-510.

669

670 ICM, 2009. Integrated Crop Management. http://agricoltura.regione.emilia-

671 romagna.it/produzioni-agroalimentari/doc/disciplinari/produzione-integrata/archivio-

672 dpi/disciplinari-di-produzione-integrata-2012. Last visit October $1^{\text {st }}, 2014$

673 
677

678

679

680

681

682

683

684

685

686

687

688

689

690

691

692

693

694

695

696

Jaafar, N. M., Clode, P. L., Abbott, L. K., 2014. Microscopy observations of habitable space in biochar for colonization by fungal hyphae from soil. J. Integrative Agric.

13(3), 483-490.

Jones, D. L., Rousk, J., Edwards-Jones, G., DeLuca, T. H., Murphy, D. V., 2012.

Biochar-mediated changes in soil quality and plant growth in a three year field trial. Soil Biol. Biochem. 45, 113-124.

Joseph, S., Camps-Arbestain, M., Lin, Y., Munroe, P., Chia, C.H., Hook, J., Van

Zwieten, L., Kimber, S., Cowie, A., Singh, B. P., Lehmann, J., Foidl, N., Smernik, R. J.

2010. An investigation into reactions of biochar in soil. Aust. J. Soil Res. 48, 501-515.

Jury, W.A., Gardner, W.R., Gardner, W.H., 1991. Eds. Soil Physics, ed., John Wiley \& Sons, New York.

Kammann, C. I., Schmidt, H.P., Messerschmidt, N., Linsel, S., Steffens, D., Müller, C., Koyro, H-W., Pellegrino, C., Stephen, J.. 2015. Plant growth improvement mediated by nitrate capture in co-composted biochar. Scientific reports, 5.

Keiluweit, M., Nico, P.S., Johnson, M.G., Kleber, M., 2010. Dynamic molecular structure of plant biomass-derived black carbon (biochar). Environ. Sci. Technol. 44(4), 1247-53 
697 Kuzyakov, Y., Bogomolova, I., Glaser, B., 2014. Biochar stability in soil:

698 Decomposition during eight years and transformation as assessed by compound-specific

699 14C analysis. Soil Biol. Biochem. 70, 229-236

700

701 Laine, J., Yunes, S., 1992. Effect of the preparation method on the pore size distribution 702 of activated carbon from coconut shell. Carbon 30, 601-604.

703

704 LeCroy, C., Masiello, C.A., Rudgers, J.A., Hockaday, W.C., Silberg, J.J., 2013.

705 Nitrogen, biochar, and mycorrhizae: Alteration of the symbiosis and oxidation of the 706 char surface. Soil Biol. Biochem. 58, 248-254.

707

708 Lehmann, J., Czimczik, C., Laird, D., Sohi, S. 2009. Stability of biochar in soil. In 709 Biochar for environmental management: science and technology, Lehmann, J., Joseph, 710 S., Eds., Earthscan: London 2009, pp 183-206

711

712 Lehmann, J., Rillig, M.C., Thies, J., Masiello, C.A., Hockaday,W.C., Crowley, D., 713 2011. Biochar effects on soil biota-a review. Soil Biol. Biochem. 43(9), 1812-1836.

714

715 Liang, B., Lehmann, J., Solomon, D., Kinyangi, J., Grossman, J., O'neill, B., Neves, E. 716 G., 2006. Black carbon increases cation exchange capacity in soils. Soil Sci. Soc. Am. J. 717 70(5), 1719-1730.

718 
719 Lin, Y., Munroe, P., Joseph, S., Kimber, S., Van Zwieten, L., 2012. Nanoscale organo720 mineral reactions of biochars in ferrosol: an investigation using microscopy. Plant Soil $721357,369-380$.

722

723 Littell, R.C., Henry, P.R., Ammerman, C. B., 1998. Statistical analysis of repeated

724 measures data using SAS procedures. J. Anim. Sci. Biotechnol. 76(4), 1216-1231

725

726 Major, J., Steiner, C., Downie, A., Lehmann, J. Biochar effects on nutrient leaching. In 727 Biochar for environmental management: science and technology, Lehmann, J., Joseph,

728 S., Eds., Earthscan: London 2009, pp 271-288.

729

730 Masiello, C.A., Dugan, B., Brewer, C.E., Spokas, K., Novak, J. M., Liu, Z., Sorrenti, 731 G., 2015. Biochar effects on soil hydrology. In Biochar for environmental management: 732 science and technology and Implementation, Lehmann, J., Joseph, S., Eds., Routledg $2^{\text {nd }}$ 733 Edition London 2009, pp 541-560.

734

735

Montes-Morán, M.A., Suárez, D., Menéndez, J.A., Fuente, E., 2004. On the nature of basic sites on carbon surfaces: an overview. Carbon 42(7), 1219-1225.

737

Mukherjee, A., Zimmerman, A. R., 2013. Organic carbon and nutrient release from a 739 range of laboratory-produced biochars and biochar-soil mixtures. Geoderma 193, 122-

740 130.

741 
742 Nguyen, B.T., Lehmann, J., Hockaday, W.C., Joseph, S., Masiello, C.A., 2010.

743 Temperature sensitivity of black carbon decomposition and oxidation. Environ. Sci.

744 Technol. 44 (9), 3324-3331.

745

746 Norwood, M. J., Louchouarn, P., Kuo, L.J., Harvey, O. R., 2013. Characterization and

747 biodegradation of water-soluble biomarkers and organic carbon extracted from low

748 temperature chars. Org. Geochem. 56, 111-119.

749

750 Novak, J.M., Busscher, W.J., Watts, D.W., Amonette, J. E., Ippolito, J.A., Lima, I. M.,

751 Gaskin, J., Das, K.C., Steiner, C., Ahmedna, M., Rehrah, D., Schomberg, H., 2012.

752 Biochars Impact on Soil-Moisture Storage in an Ultisol and Two-Aridisols. Soil Sci.

$753 \quad 177,310-320$.

754

755 Nguyen, B.T., Lehmann, J., Kinyangi, J., Smernik, R., Riha, S.J., Engelhard, M.H., 756 2008. Long-term black carbon dynamics in cultivated soil. Biogeochem. 89, 295-308.

757

758 Oguntunde, P.G., Abiodun, B.J., Ajayi, A.E., van de Giesen, N., 2008. Effects of

759 charcoal production on soil physical properties in Ghana. J. Plant Nutr. Soil Sci. 171, $760 \quad 591-596$.

761

762 Rajkovich, S., Enders, A., Hanley, K., Hyland, C., Zimmerman, A.R., Lehmann, J.

763 2012. Corn growth and nitrogen nutrition after additions of biochars with varying

764 properties to a temperate soil. Biol. Fertil. Soils 48(3), 271-284.

765 
766 Pietikäinen, J., Kiikkila, O., Fritze, H., 2000. Charcoal as a habitat for microbes and its

767 effect on the microbial community of the underlying humus. Oikos 89, 231-242.

768

769 Qian, L., Chen, B., 2014. Interactions of Aluminium with Biochars and Oxidized

770 Biochars: Implications for the Biochar Aging Process. J. Agric. Food Chem. 62(2),

$771 \quad 373-380$.

772

773 Saville, D.J., Rowarth, J.S., 2008. Statistical measures, hypotheses, and tests in applied 774 research. J. Natural Resources and Life Sci. Education 37, 74-82.

775

776 Shinogi, Y., Yoshida, H., Koizumi, T., Yamaoka, M., Saito, T. 2003. Basic

777 characteristics of low-temperature carbon products from waste sludge. Adv. Envir. Res.

$778 \quad 7(3), 661-665$.

779

780 Spokas, K., Baker, J., Reicosky, D., 2010. Ethylene: Potential key for biochar

781 amendment impacts. Plant Soil 333, 443-452.

782

783 Spokas, K.A., Cantrell, K.B., Novak, J. M., Archer, D.W., Ippolito, J.A., Collins, H. P., 784 Boateng, A.A., Lima, I.M., Lamb, M.C., McAloon, A. J., Lentz, R.D., Nichols, K.A., 785 2012. Biochar: a synthesis of its agronomic impact beyond carbon sequestration. J.

786 Environ. Qual. 41(4), 973-989.

787

788 Spokas, K. A., 2013. Impact of biochar field aging on laboratory greenhouse gas

789 production potentials. GCB Bioenergy 5(2), 165-176. 
Spokas, K.A., Novak, J.M., Masiello, C.A., Johnson, M.G., Colosky, E.C., Ippolito, J.

A., Trigo, C., 2014. Physical Disintegration of Biochar: An Overlooked Process.

Environ. Sci. Technol. Lett. 1, 326-332.

794

Steiner, C., Glaser, B., Teixeira, W.G., Lehmann, J., Blum, W.E.H., Zech, W., 2008.

Nitrogen retention and plant uptake on a highly weathered central amazonian ferralsol amended with compost and charcoal. J. Plant Nutr.Soil Sci.-Zeitschrift Fur

Pflanzenernahrung Und Bodenkunde 171, 893-899.

799

800

Sun, H., Hockaday, W.C., Masiello, C.A., Zygourakis, K., 2012. Multiple controls on the chemical and physical structure of biochars. Ind. Eng. Chem. Res. 51(9), 3587-97.

802

803

Thies, J., Rillig, M. 2009. Characteristics of biochar: biological properties. In Biochar 804 for environmental management: science and technology, Lehmann, J., Joseph, S., Eds.,

805 Earthscan: London, pp 85-106.

806

Van Zwieten, L., Kimber, S., Morris, S., Chan, K. Y., Downie, A., Rust, J., Joseph, S., 808 Cowie, A., 2010. Effects of biochar from slow pyrolysis of papermill waste on 809 agronomic performance and soil fertility. Plant Soil 327, 235-246

810

811 Verheijen, F., Jeffery, S., Bastos, A.C., van der Velde, M., Diafas, I., 2010. Biochar

812 Application to Soils: A Critical Scientific Review of Effects on Soil Properties, 813 Processes and Functions. Joint Research Centre (JRC) Scientific and Technical Report 
No EUR 24099 EN, Office for the Official Publications of the European Communities,

815 Luxembourg.

816

817 Warnock, D.D., Lehmann, J., Kuyper, T.W., Rillig, M.C., 2007 Mycorrhizal responses

818 to biochar in soil: concepts and mechanisms. Plant Soil 300:(1-2), 9-20.

819

820 Wildman, J., Derbyshire, F. 1991. Origins and functions of macroporosity in activated 821 carbons from coal and wood precursors. Fuel 70(5), 655-661.

822

823 Woolf, D., Amonette, J. E., Street-Perrott, F. A., Lehmann, J., Joseph, S. 2010.

824 Sustainable biochar to mitigate global climate change. Nat. Commun., 1, 56.

825

826 Yan, F., Schubert, S., Mengel, K..1996. Soil pH increase due to biological

827 decarboxylation of organic anions. Soil Biol. Biochem. 28, 617-624.

828

829 Yao, F.X., Arbestain, M.C., Virgel, S., Blanco, F., Arostegui, J., Macia-Agullo, J.A.,

830 Macias, F., 2010. Simulated geochemical weathering of a mineral ash-rich biochar in a

831 modified Soxhlet reactor. Chemosphere 80, 724-732.

832

833 Zimmerman, A.R., 2010. Abiotic and microbial oxidation of laboratory-produced black 834 carbon (biochar). Environ. Sci. Technol. 44(4), 1295-1301. 